\title{
Floral capitula and essential oil production analysis of chamomile (Chamomilla recutita) cultivars at different times of harvest
}
Análisis de la producción de capítulos florales y aceite esencial de cultivares de manzanilla (Chamomilla recutita) en diferentes épocas de cosecha

MILTON S. MATSUSHITA', 2

CÍCERO DESCHAMPS ${ }^{1}$

CIRINO CORRÊA JÚNIOR'

MARÍLIA P. MACHADO'

Floral capitula of chamomile.

Photo: C. Corrêa Júnior

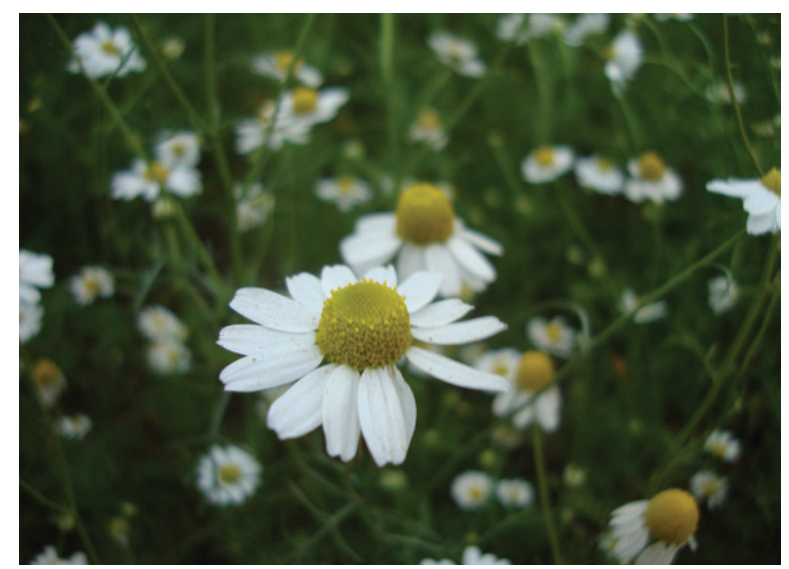

\begin{abstract}
Chamomile [Chamomilla recutita (L.) Rauschert] belongs to the Asteraceae family and is part of a large medicinal plant group that is cultivated and used in Brazil and in the world. The objective of this study was to evaluate the floral capitula productivity and essential oil content and composition of four cultivars of chamomile in three harvesting periods. The experiment was conducted at the Canguiri Experimental Station (UFPR) from May $15^{\text {th }}$ to September $9^{\text {th }}, 2015$. Four cultivars of chamomile were evaluated, from commercial products purchased in different countries: Twinings (England), Auchan (Spain), Lipton (Scotland) and Mandirituba (Brazil), which is traditionally grown in Paraná. The experiment design used randomized blocks in a $4 \times 3$ factorial scheme (4 cultivars and 3 harvesting periods), with four replicates. At 96 days after planting, manual harvests were performed, for a total of three harvests. After each harvest, the floral chapters were dried. The extraction of the essential oil and the identification of the chemical constituents of the essential oil were carried out in the Laboratory of Ecophysiology of UFPR. The harvest time affected the productivity of the floral capitula and essential oil, being higher in the first (276.9 and $0.71 \mathrm{~kg} \mathrm{ha}^{-1}$, respectively) and third harvests (262.6 and $0.77 \mathrm{~kg} \mathrm{ha}^{-1}$, respectively). The cultivars and harvests did not influence the essential oil percentage ( 0.22 to $0.29 \%$ ) obtained from the floral capitula; however, they contributed to the definition of the produced chemical compound.
\end{abstract}

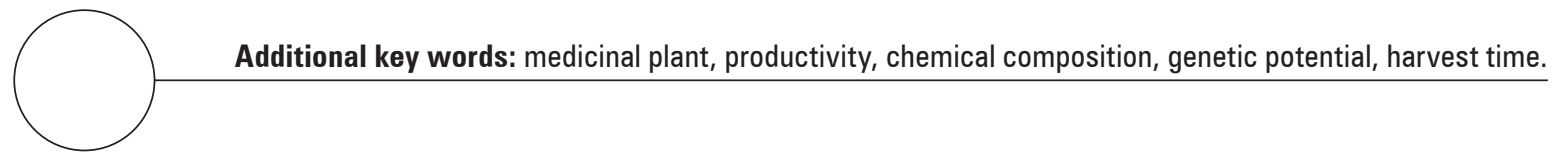

1 Instituto Emater, Universidade Federal do Parana, Curitiba-PR (Brazil). ORCID Matsushita, M.S.: 0000-0002-9970-2613; ORCID Deschamps, C.: 0000-0003-0786-0532; ORCID Corrêa Júnior, C.: 0000-0002-5234-4409; ORCID Machado, M.P.: 0000-0002-3209-4780

2 Corresponding author. matsushita@emater.pr.gov.br 


\section{RESUMEN}

La manzanilla [Chamomilla recutita (L.) Rauschert] pertenece a la familia Asteraceae y es parte de un gran grupo de plantas medicinales cultivadas y utilizadas en Brasil y en todo el mundo. El objetivo de este estudio fue evaluar la productividad de capítulos florales junto con el contenido y composición del aceite esencial de cuatro cultivares de manzanilla en tres períodos de cosecha. Se ha llevado a cabo el experimento en la Estación Experimental de Canguiri (UFPR) en el período del 15 de mayo hasta el 09 septiembre de 2015. Se evaluaron cuatro cultivares comerciales de manzanilla adquiridos en diferentes países: Twinings (Inglaterra), Auchan (España), Lipton (Escocia) y Mandirituba (Brasil), que tradicionalmente se cultivan en Paraná. El diseño experimental fue de bloques al azar a través de un factorial $4 \times 3$ ( 4 cultivares y 3 períodos de cosecha) y con cuatro repeticiones. A los 96 días tras la plantación se realizaron cosechas manuales, en un total de tres cosechas. Después de cada cosecha, se sometieron los capítulos a secado. La extracción de aceite esencial y la identificación de los componentes químicos del aceite esencial se realizaron en el Laboratorio de Ecofisiología de UFPR. La época de cosecha afectó la producción de capítulos y aceite esencial, siendo mayor en la primera $\left(276,9\right.$ y $0,71 \mathrm{~kg} \mathrm{ha}^{-1}$, respectivamente) y tercera cosechas $(262,6$ y 0,77 $\mathrm{kg} \mathrm{ha}^{-1}$, respectivamente). Los cultivares y las cosechas no tuvieron influencia sobre el porcentaje de aceite esencial $(0,22$ a $0,29 \%)$ obtenido de los capítulos de las flores, pero contribuyen con la definición del compuesto químico a producirse.

Palabras clave adicionales: planta medicinal, productividad, composición química, potencial genético, momento de cosecha.

Received for publication: 14-11-2017 Accepted for publicacation: 30-05-2018

INTRODUCTION

Chamomile [Chamomilla recutita (L.) Rauschert], belongs to the Asteraceae family and it is cultivated in many countries, including Brazil, with Paraná having the largest planted area (Corrêa Júnior et al., 2008) with 3,000 ha, producing an average of US\$ $3.5 \mathrm{mi}-$ llion per year (AEN-PR, 2016).

Chamomile is included in the pharmacopoeia of 26 countries (Salamon, 1992) and has more than 120 chemical constituents identified in the essential oil of its inflorescences (Pino et al., 2002), including 28 terpenoids, 36 flavonoids and 52 compounds with potential pharmacological activity (Singh et al., 2011). The essential oils of the different chamomile chemotypes presented the constituents cis- $\beta$-Farnesene (0.9-65.9\%), spathulenol (1.3-19.4\%), $\alpha$-bisabolol B oxide (0.1-25.1\%), $\alpha$-bisabololone A oxide (0.1$29.9 \%)$, $\alpha$-bisabolol (0.1-56.9\%), camazulene (0.2$25.5 \%)$ and $\alpha$-bisabolol A oxide (0.1-55.9\%) (Tadrent et al., 2016).

The composition and percentage of the essential oil constituents of chamomile are subject to variations because of genetic and environmental factors
(Tadrent et al., 2016). Research aimed at improving crop production technologies is important for increasing the production and quality of essential oil. Thus, the introduction of cultivars that adapt to regions of production can bring benefits to chamomile cultivation. The objective of this study was to evaluate the productivity of flower buds, the essential oil content and the composition of four cultivars of chamomile in three harvest periods.

\section{MATERIAL AND METHODS}

This experiment was conducted at the Experimental Stations Center of Canguiri (UFPR) in the municipality of Pinhais-PR $\left(25^{\circ} 23.258^{\prime} \mathrm{S}\right.$ and $40^{\circ} 07.713^{\prime} \mathrm{W}, 919$ $\mathrm{m}$ of altitude), where the climate is classified by the Köppen international system as humid mesothermal subtropical. In the period of the experiment (May $15^{\text {th }}$ through September $\left.9^{\text {th }}, 2015\right)$, the total rainfall index was $404 \mathrm{~mm}$, with an average temperature of $15.5^{\circ} \mathrm{C}$, minimum of $6.0^{\circ} \mathrm{C}$ and maximum of $32.7^{\circ} \mathrm{C}$ (Simepar, 2015). The soil of the experimental area is classified as haplic cambisol (Embrapa, 1999). For the 
chemical characteristic analysis, the soil was sampled at the depth of $0-20 \mathrm{~cm}$ in five points in the experimental area. The sample was analyzed according to Pavan et al. (1992) and presented: $\mathrm{pH} \mathrm{CaCl}_{2}=6.0$; $\mathrm{Al}^{3+}=0.0 \quad \mathrm{cmol}_{\mathrm{c}} \mathrm{dm}^{-3} ; \mathrm{H}^{+}+\mathrm{Al}^{3+}=3.7 \quad \mathrm{cmol}_{\mathrm{c}} \mathrm{dm}^{-3}$; $\mathrm{Ca}^{2+}=9.0 \mathrm{cmol}_{c} \mathrm{dm}^{-3} ; \mathrm{Mg}^{+2}=3.8 \mathrm{cmol}_{\mathrm{c}} \mathrm{dm}^{-3} ; \mathrm{K}^{+}=0.9$ $\mathrm{cmol}_{\mathrm{c}} \mathrm{dm}^{-3} ; \mathrm{P}=212 \mathrm{mg} \mathrm{dm}^{-3} ; \mathrm{C}=35.8 \mathrm{~g} \mathrm{dm}^{-3}$; base saturation of $79 \%$ and clay content of $513 \mathrm{~g} \mathrm{~kg}^{-1}$.

Four cultivars of chamomile were evaluated from commercial products purchased in different countries: Twinings (England), Auchan (Spain), Lipton (Scotland), and Mandirituba (Brasil), cultivated in Parana.

The experiment design used randomized blocks in a $4 \times 3$ factorial scheme (4 cultivars and 3 harvesting periods), with four repetitions. Each plot consisted of an area of $2 \mathrm{~m}^{2}$, where $25 \mathrm{~g}$ of seeds were used, mixed with maize corn as a vehicle at a ratio of $50: 1$ by weight. Manual seeding and compaction were carried out directly in the plots, followed by manual weeding on two occasions during the vegetative cycle, which preceded the harvests.

At $96 \mathrm{~d}$ after planting, when $70 \%$ of the petals were horizontal, manual harvesting was performed every $11 \mathrm{~d}$, totaling three crops. After each harvest, the floral chapters were dried in a dryer (Fanem, Mod. 320 SE; São Paulo-SP, Brazil) with air circulation, at a temperature of $65^{\circ} \mathrm{C}$ for $24 \mathrm{~h}$. For the determination of the oil content on dry basis, $20 \mathrm{~g}$ subsamples were dried in a dryer at $65^{\circ} \mathrm{C}$ until constant mass.

The extraction of the essential oil was carried out with hydrodistillation for $4 \mathrm{~h}$ in a Clevenger type graded apparatus using $50 \mathrm{~g}$ of dried capitulas in $1 \mathrm{~L}$ of distilled water. The mixture of the essential oil and water vapors was separated with the density difference after condensation. After extraction, the samples were stored at $-20^{\circ} \mathrm{C}$, where they remained until the time of analysis.

The chemical constituents of the essential oil were identified with gas chromatography coupled to a mass spectrometer (GC/MS). The chromatograph was the Varian model CP-3800, with a Saturn 2000 MS/MS detector (Varian Inc., Walnut Creek, CA, USA) and a fused silica column, $100 \mathrm{~m}$ in length (stationary phase PONA). Helium gas was used to lower the pressure to $49.5 \mathrm{psi}$. The initial temperature was $120^{\circ} \mathrm{C}$ for $22 \mathrm{~min}$, which was then elevated to $230^{\circ} \mathrm{C}$ for $20 \mathrm{~min}$ with a heating rate of $10^{\circ} \mathrm{C} / \mathrm{min}$. The 0.2 $\mu \mathrm{L}$ of essential oil was injected with a 200 split ratio and injection temperature of $200^{\circ} \mathrm{C}$. The identification of the chemical constituents was done by comparing the Nist 98 (Varian Inc.) library with the mass spectra obtained for each compound.

The data were submitted to the Bartlett test to verify the homogeneity of the variances and then to analysis of variance (ANOVA). The means were compared with the Tukey test at 5\% probability, using the statistical program Assistat version 7.7 beta (Silva and Azevedo, 2006).

\section{RESULTS AND DISCUSSION}

The chamomile cultivars did not present statistical differences in relation to the productivity of the floral capitula, obtaining productivity of 662.8 to $808.3 \mathrm{~kg}$ $\mathrm{ha}^{-1}$. However, the harvest influenced the productivity of the floral capitula and yield of essential oil. Greater floral capitulum and essential oil yields were observed in the first and third harvests, respectively (Tab. 1). The results found in all cut periods were higher for the cultivar Mandirituba, when compared to the productivity of the chapters for the same cultivar obtained by Amaral et al. (2012), $510.0 \mathrm{~kg} \mathrm{ha}^{-1}$.

The cultivars and time of crops did not affect the percentage of essential oil. An average $0.29 \%$ of essential oil was obtained from the floral capitula in the cultivar Lipton, being only that Twinings in the third harvest presented the minimum level $(0.40 \%)$ (Tab. 1) allowed by the Brazilian Pharmacopoeia (1996) for use as a plant drug. The Mandirituba cultivar presented an essential oil content of $0.47 \%$ when cultivated in the municipality of Piraquara (PR) (Amaral et al., 2012). However, Corrêa Júnior (1995) obtained high levels of essential oil for the same cultivar $(0.80 \%)$. This demonstrates that environmental factors must be related to the low levels of essential oil obtained in the present study for the Mandirituba cultivar. For the other cultivars, new research is needed to know the maximum potential of each one.

Schilcher (1973) and Motl et al. (1977) documented the large variation in the content of individual constituents that chamomile oil may present. Despite the differences between the authors, the results found in the present study are within the ranges described for the major constituents obtained in the essential oil of the four cultivars (Tab. 2). 


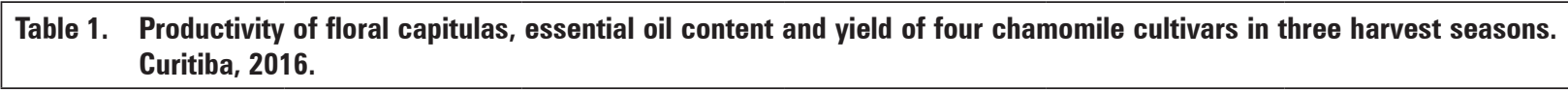

\begin{tabular}{|c|c|c|c|c|c|}
\hline \multirow{2}{*}{ Cultivar } & \multicolumn{4}{|c|}{ Floral capitulas $\left(\mathrm{kg} \mathrm{ha}^{-1}\right)$} & \multirow[b]{2}{*}{ Mean $^{n}$} \\
\hline & $1^{\text {st }}$ harvest & $2^{\text {nd }}$ harvest & $3^{\text {rd }}$ harvest & Amount & \\
\hline Twinings & 314.8 & 181.2 & 263.7 & 759.7 & 253.2 \\
\hline Auchan & 215.9 & 175.3 & 271.6 & 662.8 & 220.9 \\
\hline Lipton & 250.3 & 182.8 & 247.1 & 680.2 & 226.7 \\
\hline Mandirituba & 326.6 & 213.7 & 268.0 & 808.3 & 269.4 \\
\hline Mean** & 276.9 a & 188.2 b & 262.6 a & & \\
\hline \multirow{2}{*}{ Cultivar } & \multicolumn{4}{|c|}{ Essential oil $\left(\mathrm{kg} \mathrm{ha}^{-1}\right)$} & \\
\hline & $1^{\text {st }}$ harvest & $2^{\text {nd }}$ harvest & $3^{\text {rd }}$ harvest & Amount & Mean \\
\hline Twinings & 0.72 & 0.39 & 0.52 & 1.63 & 0.54 \\
\hline Auchan & 0.54 & 0.50 & 0.70 & 1.74 & 0.58 \\
\hline Lipton & 0.68 & 0.33 & 0.95 & 1.96 & 0.65 \\
\hline Mandirituba & 0.95 & 0.40 & 0.86 & 2.21 & 0.74 \\
\hline Mean** & $0.71 \mathrm{a}$ & $0.40 \mathrm{~b}$ & $0.77 \mathrm{a}$ & & \\
\hline \multirow{2}{*}{ Cultivar } & \multicolumn{4}{|c|}{ Essential oil (\%) } & \\
\hline & $1^{\text {st }}$ harvest & $2^{\text {nd }}$ harvest & $3^{\text {rd }}$ harvest & Mean ${ }^{\text {ns }}$ & \\
\hline Twinings & 0.24 & 0.21 & 0.20 & 0.22 & \\
\hline Auchan & 0.23 & 0.28 & 0.26 & 0.25 & \\
\hline Lipton & 0.28 & 0.18 & 0.40 & 0.29 & \\
\hline Mandirituba & 0.28 & 0.19 & 0.32 & 0.26 & \\
\hline Mean ${ }^{\text {ns }}$ & 0.26 & 0.22 & 0.29 & & \\
\hline
\end{tabular}

Means followed by the same letter in the line do not differ statistically by the Tukey test $(P \leq 0.01)$.

ns: not significant; ${ }^{*}$ : significant at $1 \%$ probability by analysis of variance (ANOVA).

The compound (E)- $\beta$-farnesene is a sesquiterpene hydrocarbon and was identified in the essential oil of the four evaluated cultivars, but with no significant difference between them. Only the harvest period was significant for this constituent, being highest in the third harvest (14.9\%) (Tab. 2). Different chamomile cultivars in Egypt showed similar results for (E)- $\beta$-farnesene (11.34-13.29\%) (Hendawy et al., 2015). IAn increase of the percentage of (E)- $\beta$-farnesene was observed in all cultivars in the third harvest. This increase may have occurred because of an induction caused by some type of stress since (E)- $\beta$-farnesene has a high potential for stress protection (Palmer-Young et al., 2015). In Pinus taeda, for example, high luminosity and temperatures induce the emission of (E)- $\beta$-farnesene (Helmig et al., 2006), and, in corn, emission is induced by injuries caused by herbivores (Schmelz et al., 2001), suggesting that (E)- $\beta$-farnesene can mediate tolerance to biotic and abiotic stress.

The most important oxidation products of $\alpha$-bisabolol are $\alpha$-bisabolol $\mathrm{A}$ and $\mathrm{B}$ oxides. The anti-inflammatory and spasmolytic effects of $\alpha$-bisabolol oxides are widely discussed in the literature (Bezerr et al., 2009; Waleczec et al., 2003; Silva et al., 2005; Mckay and Blumberg, 2006; Neuhaus-Carlisle et al., 1997), demonstrating the importance of these constituents. The cultivars presented statistical differences for the $\alpha$-bisabolol A oxide and $\alpha$-bisabolol B oxide. Lipton presented the highest percentages for $\alpha$-bisabolol A oxide $(27.2 \%)$ and $\alpha$-bisabolol B oxide (20.3\%). On the other hand, the cultivar Twinings presented a high percentage of $\alpha$-bisabolol A oxide (26.5\%) and the lowest percentage of $\alpha$-bisabolol B oxide (9.9\%). For all of the cultivars, the first harvest yielded a higher percentage of $\alpha$-bisabolol A oxide, and the harvesting season did not affect the amount of $\alpha$-bisabolol B oxide (Tab. 2). In chamomile cultivars grown in Egypt, Hendawy et al. (2015) obtained percentages of $\alpha$-bisabolol A oxide higher than those found in this study $(44.68-53.93 \%)$.

Another important constituent of chamomile essential oil (Nogueira and Minetto, 2005) is camazulene because of its anti-inflammatory effect, which presented a variation of 3.2 to $4.0 \%$ in the three harvest periods; no statistical difference was observed among 
Table 2. Chemical constituents of Chamomilla recutita essential oil cultivars at three harvest times. Curitiba, 2016.

\begin{tabular}{|c|c|c|c|c|}
\hline \multirow{2}{*}{ Cultivar } & \multicolumn{4}{|c|}{ (E)- $\beta$-farnesene (\%) } \\
\hline & $1^{\text {st }}$ harvest & $2^{\text {nd }}$ harvest & $3^{\text {rd }}$ harvest & Mean ${ }^{\text {ns }}$ \\
\hline Twinings & 8.7 & 14.3 & 15.9 & 13.0 \\
\hline Auchan & 10.2 & 10.4 & 14.0 & 11.6 \\
\hline Lipton & 11.1 & 11.8 & 13.9 & 12.3 \\
\hline Mandirituba & 9.4 & 10.4 & 15.7 & 11.9 \\
\hline Mean** & $9.9 \mathrm{c}$ & $11.7 \mathrm{~b}$ & $14.9 \mathrm{a}$ & \\
\hline Cultivar & \multicolumn{3}{|c|}{ Dehydro-sesquicineole (\%) } & Mean** \\
\hline Twinings & 4.5 & 4.9 & 4.4 & $4.6 \mathrm{a}$ \\
\hline Auchan & 2.1 & 2.8 & 2.5 & $2.5 \mathrm{c}$ \\
\hline Lipton & 1.7 & 1.5 & 1.8 & $1.6 \mathrm{~d}$ \\
\hline Mandirituba & 3.0 & 3.7 & 3.4 & $3.4 \mathrm{~b}$ \\
\hline Mean $^{\text {ns }}$ & 2.8 & 3.2 & 3.0 & \\
\hline$\overline{\text { Cultivar }}$ & \multicolumn{3}{|c|}{$\alpha$-bisabolol A oxide (\%) } & Mean ** \\
\hline Twinings & 27.9 & 26.0 & 25.7 & $26.5 \mathrm{a}$ \\
\hline Auchan & 25.4 & 24.1 & 22.7 & $24.1 \mathrm{~b}$ \\
\hline Lipton & 27.5 & 28.8 & 25.3 & $27.2 \mathrm{a}$ \\
\hline Mandirituba & 24.7 & 23.8 & 23.7 & $24.1 \mathrm{~b}$ \\
\hline Mean** & $26.4 \mathrm{a}$ & $25.7 \mathrm{ab}$ & $24.4 \mathrm{~b}$ & \\
\hline Cultivar & \multicolumn{3}{|c|}{$\alpha$-bisabolol B oxide (\%) } & Mean** \\
\hline Twinings & 10.4 & 10.9 & 8.5 & $9.9 \mathrm{c}$ \\
\hline Auchan & 20.3 & 20.6 & 19.6 & $20.1 \mathrm{a}$ \\
\hline Lipton & 20.7 & 20.6 & 19.6 & $20.3 \mathrm{a}$ \\
\hline Mandirituba & 17.7 & 17.2 & 13.6 & $16.2 b$ \\
\hline Mean $^{\text {ns }}$ & 17.3 & 17.3 & 15.3 & \\
\hline Cultivar & \multicolumn{3}{|c|}{ Epi-o-bisabolol (\%) } & Mean** \\
\hline Twinings & 9.2 & 7.1 & 6.0 & $7.4 \mathrm{a}$ \\
\hline Auchan & 8.4 & 8.2 & 6.4 & $7.7 \mathrm{a}$ \\
\hline Lipton & 4.6 & 4.6 & 5.1 & $4.8 \mathrm{~b}$ \\
\hline Mandirituba & 6.8 & 6.9 & 6.2 & $6.6 a b$ \\
\hline Mean $^{\text {ns }}$ & 7.3 & 6.7 & 5.9 & \\
\hline Cultivar & \multicolumn{3}{|c|}{ Camazulene (\%) } & Mean $^{\text {ns }}$ \\
\hline Twinings & 3.6 & 2.9 & 3.6 & 3.4 \\
\hline Auchan & 3.8 & 3.4 & 4.0 & 3.7 \\
\hline Lipton & 2.7 & 3.0 & 4.0 & 3.2 \\
\hline Mandirituba & 3.3 & 3.4 & 4.7 & 3.8 \\
\hline Mean** $^{*}$ & $3.4 \mathrm{ab}$ & $3.2 b$ & $4.0 \mathrm{a}$ & \\
\hline Cultivar & \multicolumn{3}{|c|}{ (Z)-Spiro-ether (\%) } & Mean $^{\text {ns }}$ \\
\hline Twinings & 12.7 & 12.4 & 14.5 & 13.2 \\
\hline Auchan & 9.5 & 13.6 & 12.4 & 11.8 \\
\hline Lipton & 13.8 & 12.9 & 12.5 & 13.1 \\
\hline Mandirituba & 13.8 & 14.1 & 12.9 & 13.6 \\
\hline Meanns & 12.5 & 13.3 & 13.1 & 12.9 \\
\hline
\end{tabular}

Means followed by the same letter in the line do not differ statistically by the Tukey test $(P \leq 0.01)$.

ns: not significant; **: significant at $1 \%$ probability by analysis of variance (ANOVA). 
the cultivars (Tab. 2). In the third harvest period, the cultivar Mandirituba presented $4.7 \%$ camazulene, a similar result to that found for the same cultivar in the municipality of Piraquara-PR (Amaral et al., 2012). Higher percentages of camazulene were obtained from essential oil extracted from chamomile in Iran (15.12\%) (Amiri and Sharafzadeh, 2014) and in Cuba (14.1\%) (Pino et al., 2000). Khourgami et al. (2012) verified that plant density and nitrogen doses supplied to plants resulted in an increase of camazulene in chamomile essential oil. Recent research has also shown that it is possible to increase the percentage of camazulene extracted from the essential oil of chamomile by modifying its extraction method (Homami et al., 2016).

The compound $\alpha$-bisabolol, an oxygenated sesquiterpene, was found in one of its isomeric forms, epi- $\alpha$-bisabolol; the percentage of this constituent in the essential oil was only influenced by the cultivars. Twinings and Auchan presented the higher percentages of epi- $\alpha$-bisabolol, 7.4 and $7.7 \%$, respectively, in relation to the Lipton cultivar (4.8\%) (Tab. 2).

Variations observed in the yield of the floral capitula, essential oil and percentage of major compounds were affected mainly by the harvesting periods, as reflected in the characteristics of the chamomile oil. This indicates that the development of harvesting technologies for chamomile cultures is important so that cultivars can express their full genetic potential with increased productivity and essential oil quality.

\section{CONCLUSION}

The productivity of the chamomile capitula ranged from 188.2 to $276.9 \mathrm{~kg} \mathrm{ha}^{-1}$ among the three harvest seasons, and higher yields were found in the first and third harvests. The chamomile cultivars showed no statistical differences in the productivity of the capitula, obtaining productivity of 662.8 to $808.2 \mathrm{~kg} \mathrm{ha}^{-1}$. The productivity of the cultivars exceeded the average productivity of Curitiba, which is $500.0 \mathrm{~kg}$ ha 1. The essential oil contents were not influenced by the harvest times or cultivars, varying from 0.22 to $0.29 \%$. The essential oil productivity was significantly influenced by the harvest season, with the higher yields found in the first $\left(0.71 \mathrm{~kg} \mathrm{ha}^{-1}\right)$ and third $(0.77$ $\mathrm{kg} \mathrm{ha}^{-1}$ ) harvests.

The camazulene percentages in the essential oil were influenced by the different harvesting times, but there was no influence from the cultivars. Among the constituents evaluated, only $\alpha$-bisabolol A was affected by the harvest time and cultivars.

The Mandirituba cultivar, used as a reference, showed higher productivity of the floral capitula and essential oil for the analyzed cultivars.

\section{ACKNOWLEDGMENTS}

The authors would like to thank the Postgraduate Program in Agronomy (Plant Production) of the Federal University of Parana for support in conducting experiments and analyzes and the Paranaense Institute of Technical Assistance and Rural Extension for the authorization of the postdoctoral internship of the first author.

Conflict of interests: the manuscript was prepared and reviewed with the participation of the authors, who declare that there exists no conflict of interest that puts the validity of the presented results at risk.

\section{BIBLIOGRAPHIC REFERENCES}

Amaral, W., C. Deschamps, M.P. Machado, H.S. Koehler, A.P. Scheer, L. Cocco, and C. Yamamoto. 2012. Avaliação de germoplasma de camomila e densidade de semeadura na produção e composição do óleo essencial. Hortic. Bras. 30(2), 195-200. Doi: 10.1590/ S0102-05362012000200003

Amiri, S. and S. Sharafzadeh. 2014. Essential oil components of German chamomile cultivated in Firoozabad, Iran. Orient. J. Chem. 30(1), 365-367. Doi: 10.13005/ ojc/300151

Bezerra, S.B., L.K.A.M. Leal, N.A.P. Nogueira, and A.R. Campos. 2009. Bisabolol-induced gastroprotection against acute gastric lesions: role of prostaglandins, nitric oxide, and $\mathrm{K}^{+}$ATP channels. J. Medic. Food 12, 1403-1406. Doi: 10.1089/jmf.2008.0290

Corrêa Júnior, C. 1995. "Mandirituba": nova cultivar brasileira de camomila. Hortic. Bras. 13, 61.

Corrêa Júnior, C., M.C. Scheffer, A.V. Borsato, and E. Dranka. 2008. O cultivo da camomila [Chamomilla recutita (L.) Rauschert]. Instituto Emater, Curitiba, Brazil.

Embrapa. 1999. Sistema Brasileiro de Classificação de Solos. Embrapa-CNPS, Rio de Janeiro, Brazil.

Helmig, H., J. Ortega, A. Guenther, J.D. Herrick, and C. Geron. 2006. Sesquiterpene emissions from loblolly pine and their potential contribution to biogenic aerosol formation in the Southeastern US. 
Atmos. Environ. 40(22), 4150-4157. Doi: 10.1016/j. atmosenv.2006.02.035

Hendawy, S.F., A.G. El-Gendy, A.E. El-Gohary, M.S. Hussein, K. Danova, and E.A. Omer. 2015. Evaluation of biomass formation, essential oil yield and composition of four different Matricaria recutita L. cultivars grown in Egypt. World J. Pharm. Sci. 3(5), 830-839.

Homami, S.S., K. Jaimand, M.B. Rezaee, and R. Afzalzadeh. 2016. Comparative studies of different extraction methods of essential oil from Matricaria recutita L. Iran. J. Chil. Chem. Soc. 61(2), 2982-2984. Doi: 10.4067/ S0717-97072016000200026

Khourgami, A., G. Sharafi, D. Ahmadiand, and Z. Bitarafan. 2012. Changes of German chamomile essential oil content in response to different plant densities and nitrogen rates. Int. J. Sci. Adv. Technol. 2(4), 19-24.

Mckay, D.L. and J.B. Blumberg. 2006. A review of the bioactive and potential health benefits ofchamomiletea (Matricaria recutita L.). Phytother. Res. 20, 519-530. Doi: $10.1002 /$ ptr.1900

Motl, O., M. Felklová, V. Lukes, and M. Jasicovà. 1977. GLC analysis and chemical types of chamomile essential oil. Arch. Pharm. 310(3), 210-215. Doi: 10.1002/ ardp.19773100306

Neuhaus-Carlisle, K., W. Vierling, and H. Wagner. 1997. Screening of plant extracts and plant constituents for calcium-channel blocking activity. Phytomedicine 4(1), 67-69. Doi: 10.1016/S0944-7113(97)80030-X

Nogueira, M.A. and A. Minetto. 2004. Controle de qualidade de chás de camomila (Matricaria recutita L.) comercializados na cidade de Cascavel e regiões. Rev. Varia Sci. 4(8), 113-120.

Palmer-Young, E.C., D. Veit, J. Gershenzon, and M.C. Schuman. 2015. The sesquiterpenes (E)- $\beta$-farnesene and (E)- $\alpha$-bergamotene quench ozone but fail to protect the wild tabacco Nicotiana attenuate from ozone, UVB, and drought stresses. PLoS ONE 10(6), e0127296. Doi: 10.1371/journal.pone.0127296

Pavan, M.A., M.F. Bloch, H.C. Zempulski, M. Miyazawa, and D.C. Zoocler. 1992. Manual de análise química do solo e controle de qualidade. Instituto Agronômico do Paraná (IAPAR), Londrina, Brazil.

Pino, J.A., R. Marbot, J. Agüero, and V. Fuentes. 2000. Essential oil of chamomile Chamomilla recutita (L.) Rausch from Cuba. J. Essent. Oil Bear. Pl. 3(1), 1-3. Doi: 10.1080/0972060X.2005.10643411
Pino, J.A., F. Bayat, R. Marbot, and J. Aguero. 2002. Essential oil of chamomile Chamomilla recutita (L.) Rausch from Iran. J. Essent. Oil Res. 14, 407-408. Doi: 10.1080/10412905.2002.9699903

Salamon, I. 1992. Chamomile: a medicinal plant. The Herb, Spice, and Medicinal Plant Digest 10(1), 1-4.

Schilcher, H. 1973. Neuere Erkenntnisse bei der Qualitätsbeurteilung von Kamillenblüten bzw. Kamillenöl. Teil 2: Qualitative Beurteilung des Ätherischen Öles in Chamomillae Blüten. Planta Medica 23, 132-144.

Schmelz, E.A., H.T. Alborn, and J.H. Tumlinson. 2001. The influence of intact-plant and excised-leaf bioassay designs on volicitin and jasmonic acid-induced sesquiterpene volatile release in Zea mays. Planta 214(2), 171-179. Doi: 10.1007/s004250100603

Senkovski, A. and G. Azevedo. 2016. Conheça o Paraná que acalma o Brasil In: https://www.gazetadopovo.com. $\mathrm{br} /$ agronegocio/agricultura/conheca-o-parana-que-acalma-o-brasil-2t22uulbq85g9nfs9zn834c0z; consulted: November, 2017.

Silva, F.A.S.E. and C.A.V.A. Azevedo. 2006. A new version of the assistat - statistical assistance software. pp. 393-396. In: World Congress on Computers in Agriculture, Orlando, FL.

Silva, M.G., S.F. Oliveira, L.J. Quintans-Junior, T.M.L. Oliveira, and M.F.F.M. Diniz. 2005. Investigação do efeito analgésico central e anti-inflamatório de Conocliniopsis prasiifolia (DC) R.M. King \& H. Robinson em Roedores. Acta Farm. Bonaer. 24(4), 533-537.

Simepar (Sistema Meteorológico do Paraná). 2015. Estação meteorológica de Pinhais, Boletim. Curitiba, Brazil.

Singh, O., K. Khanam, N. Misra, and M.K. Srivastava. 2011. Chamomile (Matricaria chamomilla L.): an overview. Phcog. Rev. 5(9), 82-95. Doi: 10.4103/0973-7847.79103

Tadrent, W., A. Kabouche, R. Touzani, and Z. Kabouche. 2016. Chemotypes investigation of essential oils of Chamomile herbs: a short review. J. Mater. Environ. Sci. 7(4), 1229-1235.

Waleczek, K.J., C.H.M. Marques, B. Hempel, and P.C. Schmidt. 2003. Phase solubility studies of pure (2)- $\alpha$-bisabolol and camomile essential oil with $\beta$-cyclodextrin. Eur. J. Pharm. Biopharm. 55, 247-251. Doi: 10.1016/ S0939-6411(02)00166-2 